\title{
Desempenho de vacas leiteiras sob pastejo suplementadas com níveis de concentrado e proteína bruta
}

\section{Performance of dairy cows in pasture supplemented with levels of concentrate and crude protein}

\author{
Aline Guimarães de Oliveira ${ }^{1 *}$; Veronaldo Souza de Oliveira ${ }^{2}$; \\ Gladston Rafael de Arruda Santos²; Anselmo Domingos Ferreira Santos²; \\ Diomar Claudio dos Santos Sobrinho'; Fábio Luiz de Oliveira ${ }^{3}$; \\ José Augusto Santana ${ }^{3}$; Julianne Santiago Silva Goveia ${ }^{1}$
}

\begin{abstract}
Resumo
Este trabalho foi realizado com o objetivo de avaliar os efeitos de quatro níveis de concentrado $(0,1$, 3 e $5 \mathrm{~kg} / \mathrm{vaca} / \mathrm{dia}$ ) e dois de proteína bruta (PB) (14 e 18\% na matéria seca do concentrado) sobre o desempenho (produção e composição do leite), consumo e digestibilidade aparente de nutrientes, e teor de nitrogênio ureico plasmático (NUP) de vacas leiteiras sob pastejo rotacionado em capim Tanzânia (Panicum maximum Jacq. cv. Tanzânia). Foram utilizadas oito vacas mestiças (Holandês x Gir) com peso médio de $488 \mathrm{~kg}$ e produção média de $12 \mathrm{~kg}$ de leite $/ \mathrm{vaca} /$ dia. O delineamento experimental utilizado foi o quadrado latino $(4 \mathrm{x} 4)$, com quatro animais e quatro dietas experimentais, sendo utilizados dois quadrados simultâneos e individualizados, cada um com um nível de PB. Foram observadas influências dos níveis de $\mathrm{PB}$ sobre os consumos de $\mathrm{PB}$, carboidratos não fibrosos (CNF) e carboidratos totais $(\mathrm{CT})$. Os consumos de matéria seca (MS), PB, extrato etéreo (EE), CT, CNF e nutrientes digestíveis totais (NDT) aumentaram à medida que foram fornecidos os concentrados tanto de $14 \%$ (C14) quanto de $18 \%$ de $\mathrm{PB}(\mathrm{C} 18)$, individualmente. Os consumos de fibra em detergente neutro (FDN) diminuíram à medida que foram fornecidos os concentrados. Os níveis de $\mathrm{PB}$ não influenciaram os coeficientes de digestibilidade aparente da MS, PB, FDN, EE e CT. Contudo, houve aumento nos coeficientes de digestibilidade aparente da MS dos grupos $\mathrm{C} 14$ e C18, individualmente. Não houve influência dos níveis de concentrado e de PB sobre os níveis de NUP, produção e composição do leite. Os resultados da pesquisa demonstram que o pastejo rotacionado de capim Tanzânia sem suplementação é a melhor opção de produção de leite na época das chuvas para vacas mestiças com produção média de $12 \mathrm{~kg}$ de leite/vaca/dia.
\end{abstract}

Palavras-chave: Composição do leite, NUP, nutrição, produção do leite

\begin{abstract}
The objective of this study was to evaluate the effect of four levels of concentrate $(0,1,3$ and $5 \mathrm{~kg} /$ cow/day) and two of crude protein (CP) (14 and 18\% crude protein in dry matter of concentrate) on performance (milk production and composition), intake and apparent nutrient digestibility, and plasma
\end{abstract}

\footnotetext{
${ }^{1}$ Discentes de Mestrado em Zootecnia, Universidade Federal de Sergipe, UFS, Aracaju, SE. E-mail: alinegzoo@yahoo.com.br; diovet@ig.com.br; jussgoveia@yahoo.com.br

${ }^{2}$ Prof $^{\text {as }}$, Dept ${ }^{\text {}}$ de Zootecnia, UFS, Aracaju, SE. E-mail: veronaldo@terra.com.br; gladstonrafael@ufs.br; anselmodfsantos@yahoo. com.br

${ }^{3}$ Discentes em Zootecnia, UFS, Aracaju, SE. E-mail: flzootecnia@hotmail.com; augustopropri@hotmail.com

* Autor para correspondência
} 
urea nitrogen concentration (PUN) of lactating cows in rotational Tanzânia (Panicum maximum Jacq. cv. Tanzânia) pasture. Eight crossbred cows (Holstein-Gir) with average weight of $488 \mathrm{~kg}$ and average production of $12 \mathrm{~kg}$ of milk/cow/day, were used. The experimental design was a latin square $(4 \mathrm{x} 4)$, with four animals and four experimental diets, being used two latin squares simultaneously and individualized, each one with a CP level. Were observed influences of CP levels on CP, non-fiber carbohydrates (NFC) and total carbohydrates (TC) intakes. Dry matter (DM), crude protein, ether extract (EE), CNF, CT and total digestible nutrients (TDN) intakes increased as the concentrates were provided both as $14 \%(\mathrm{C} 14)$ to $18 \%$ CP (C18), individually. Neutral detergent fiber (NDF) intake decreased as the concentrates were provided. The CP levels did not influence the apparent digestibility of DM, CP, NDF, EE and CT. However, there was an increase in the DM apparent digestibility of groups C14 and C18 individually. No influence were observed of concentrate levels and CP on PUN, milk production and composition. The results show that the rotational grazing of Tanzania, without supplementation, is the best option for milk production during the rainy season for crossbred cows with an average production of $12 \mathrm{~kg}$ milk/ cow/day.

Key words: Milk composition, milk production, nutrition, PUN

\section{Introdução}

Um dos principais objetivos dos produtores de leite tem sido o aumento da produtividade das vacas leiteiras, sendo que este aumento depende de fatores genéticos, ambientais, sanitários, nutricionais e suas interações (TEIXEIRA et al., 2010). A produção e composição do leite pode ser modulada em curto prazo principalmente por meio do manejo alimentar. Porém, o retorno econômico do fornecimento de uma dieta melhorada depende amplamente da eficiência de conversão de nutrientes para produção de leite (BRUN-LAFLEUR et al., 2010). Nesse sentido, o bom manejo nutricional é importante para que os animais expressem seu potencial, maximizando a resposta produtiva para o uso eficiente de nutrientes (LANA, 2007).

A utilização de pastagens é a principal fonte alimentar para ruminantes no Brasil e é altamente recomendável, pois atende às exigências nutricionais de algumas categorias animais, quando as condições de umidade e temperatura são favoráveis (BRÂNCIO et al., 2003) além de ser a opção mais rentável. Contudo, vacas de alta produção não conseguem obter somente da forragem, mesmo que de boa qualidade, toda energia para alcançar seu potencial produtivo (CARVALHO et al., 2010). Para potencializar esse sistema, buscando níveis mais elevados de produção de leite, geralmente é necessária a suplementação com concentrados.
Entretanto, a sua viabilidade econômica está relacionada à resposta produtiva, aos seus custos $\mathrm{e}$ preços relativos do leite.

Para a formulação de dietas, predição do desempenho animal, planejamento e controle do sistema de produção, é necessário o conhecimento do que o animal consome, pois é o principal fator a afetar o desempenho (PINA et al., 2006). O consumo de matéria seca determina a quantidade de nutrientes disponíveis para mantença e produção de um animal e é importante na formulação de dietas para evitar super ou subalimentação, que podem causar efeitos adversos à saúde dos animais e/ou onerar os custos (NRC, 2001). Após a determinação do que pode ser consumido, constitui aspecto preponderante, a estimação dos parâmetros de digestibilidade dos alimentos permitindo o balanceamento adequado de dietas que possam atender demandas de mantença e produção dos animais (DETMANN et al., 2006).

Contudo, quando se trata de consumo a pasto pelos animais, existe grande dificuldade em estimá-lo, pois não pode ser avaliado diretamente. A coleta total de fezes é uma das ferramentas para determinação do consumo, porém requer minucioso controle do que é ingerido e excretado pelo animal, tornando-o dispendioso e trabalhoso, principalmente em pesquisas com animais em pastejo. $\mathrm{O}$ uso de indicadores aparece como uma alternativa para determinação do consumo 
e também da digestibilidade dos alimentos, não necessitando de coleta de grande quantidade de fezes. Existem dois tipos de indicadores: internos - substâncias indigestíveis presentes em algum componente da dieta, ex: FDAi e FDNi; e externos - variedade de compostos inertes fornecidos aos animais, ex: óxido crômico e LIPE®. Este é um exemplo de um eficiente indicador, no qual pode ser recuperado quase que em sua totalidade nas fezes e vem sendo bastante utilizado em diversas pesquisas com animais de diferentes espécies (LANZETTA et al., 2009).

De acordo com Brun-Lafleur et al. (2010), consumos de energia e proteína são os fatores mais críticos que podem afetar a produção de leite, quando comparado aos demais nutrientes provenientes de diferentes dietas. Reduzir a concentração de PB dietética para vacas em lactação é o modo mais comum e prático para diminuir as perdas de compostos nitrogenados e os custos de produção relacionados à alimentação. Contudo, se a redução da concentração de PB na dieta for significativamente abaixo das recomendações, ocorre redução na produção de leite. A deficiência de PB na dieta (abaixo de 7\%) provoca redução do consumo em decorrência ao não atendimento às exigências mínimas dos microrganismos ruminais (VAN SOEST, 1994). Isso ocorre devido ao baixo teor de nitrogênio que limita o crescimento microbiano, provocando redução da digestibilidade da parede celular, do consumo e, consequentemente, afetando o desempenho animal (OBEID et al., 2007).

Para o monitoramento da ingestão de proteína bruta, pode ser usado o conhecimento da concentração de ureia plasmática que deve ser o mais próximo possível das necessidades da vaca, já que o excesso de nitrogênio $(\mathrm{N})$ aumenta as exigências de energia, de modo que são necessários 13,3 kcal de energia digestível para excretar um grama de $\mathrm{N}$, como também pode prejudicar o desempenho reprodutivo.Além disso, os suplementos proteicos são caros e a grande quantidade de $\mathrm{N}$ excretada gera impacto ambiental negativo (BRODERIK; CLAYTON, 1997). Dessa forma, é desejável o uso de suplementos que resulte em elevada eficiência do metabolismo de proteínas acompanhado de baixos níveis de excreção de $\mathrm{N}$.

Estudos relacionados à ingestão de proteína dietética $\mathrm{x}$ produção de leite tem apresentado resultados diversos. Pereira et al. (2005), realizaram trabalho com níveis crescentes de PB de 12,7; 14,1; 15,5 e $16,9 \%$ na MS, para vacas no terço inicial da lactação, alimentadas com concentrado à base de fubá de milho e farelo de soja e com silagem de milho. Esses pesquisadores não observaram alterações na produção e na composição do leite em função dos níveis de PB da dieta. Jones-Endsley, Cecava e Johnson (1997) e Kalscheur et al. (1999) também não encontraram diferenças significativas para a produção e composição química do leite, ao compararem dietas contendo 12,3 ou $16,1 \%$ de PB e 13,3 ou $15,3 \%$ de $\mathrm{PB}$, respectivamente. Porém, Cordeiro et al. (2007), avaliaram o efeito de teores crescentes de PB na MS total da dieta $(11,5 ; 13,0$; 14,5 e $16,0 \%$ ) sobre a produção e composição do leite de vacas leiteiras e constataram maior produção de leite para os animais alimentados com dieta com $16,0 \%$ de PB, com melhora na produção em $26,41 \%$ ou 2,9 $\mathrm{kg}$ de leite/dia, entre os teores de 11,5 e 16,0\% de PB e para a produção de leite corrigida para 3,5\% de gordura, os acréscimos foram de $29,76 \%$ ou 3,05 $\mathrm{kg} /$ dia. Entretanto, não influenciaram a porcentagem de proteína, gordura e lactose do leite.

Realizou-se o este trabalho com o objetivo de avaliar o consumo e a digestibilidade aparente da matéria seca e de seus nutrientes, o desempenho (produção e composição do leite) e o teor de nitrogênio ureico plasmático de vacas leiteiras alimentadas com níveis de concentrado e proteína bruta sob pastejo de capim Tanzânia.

\section{Material e Métodos}

O experimento foi desenvolvido na fazenda Santa Cruz, localizada no município de Laranjeiras, 
Sergipe, em pastagem rotacionada de capim Tanzânia (Panicum maximum Jacq. cv. Tanzânia), no período de agosto a setembro de 2012, durante a estação chuvosa. A fazenda encontra-se na zona litorânea de Sergipe e tem como coordenadas geográficas a latitude $10^{\circ} 49^{\prime} 37.17^{\prime \prime}$ sul e longitude $37^{\circ} 08^{\prime} 05.47^{\prime}$ " oeste de Greenwich estando a uma altitude de 10 metros. O clima é do tipo tropical com estação seca (Classificação climática de Köppen-Geiger: As). A temperatura média anual é de $26^{\circ} \mathrm{C}$ e precipitação pluviométrica média de $1600 \mathrm{~mm}$ anuais.

Foram utilizadas oito vacas mestiças (Holandês x Gir) com peso médio de $488 \mathrm{~kg}$, período de lactação médio de 100 dias e média de produção de $12 \mathrm{~kg}$ de leite/vaca/dia. Foram testados quatro níveis de concentrados $(0,1,3$, e $5 \mathrm{~kg} / \mathrm{vaca} / \mathrm{dia})$ e dois níveis de proteína bruta (PB), 14 e 18\% PB na matéria seca total do concentrado, sobre o consumo e a digestibilidade aparente da matéria seca e de seus nutrientes, produção e composição do leite e teor de nitrogênio ureico no plasma (NUP).

O experimento teve duração de 48 dias, divididos em 4 períodos de 12 dias sendo que nestes 12 dias,
9 eram de adaptação às dietas experimentais e 5 de coleta de dados e amostras. O delineamento experimental utilizado foi o quadrado latino $(4 \times 4)$, com quatro animais e quatro dietas experimentais, sendo utilizados dois quadrados simultâneos, cada um com um nível de $\mathrm{PB}$, onde foram designados C14: grupo de animais alimentados com concentrados contendo $14 \%$ de PB; e C18: grupo de animais alimentados com concentrados contendo $18 \%$ de PB.

Os concentrados foram compostos de fubá de milho, farelo de soja e ureia e fornecidos duas vezes ao dia, metade logo após as ordenhas da manhã e a outra metade após as ordenhas da tarde, ás 8 e $16 \mathrm{~h}$ respectivamente. $\mathrm{O}$ sal mineral foi fornecido ad libitum e no período entre as ordenhas, os animais tiveram livre acesso à pastagem. A composição nutricional do capim Tanzânia, fubá de milho e farelo de soja encontra-se na Tabela 1 e a dos concentrados na Tabela 2. O pastejo rotacionado era composto por 15 piquetes de capim Tanzânia, implantada há 10 anos, recebendo adubação nitrogenada de $200 \mathrm{~kg}$ de N/ha./ano na forma de ureia.

Tabela 1. Composição nutricional do capim Tanzânia, do fubá de milho e do farelo de soja.

\begin{tabular}{lccc}
\hline \multicolumn{1}{c}{ Composição nutricional (\%MS) } & Tanzânia & Fubá de milho & Farelo de soja \\
\hline Matéria seca (\%) & 26,51 & 86,22 & 85,09 \\
Proteína bruta & 13,43 & 9,47 & 45,51 \\
Proteína indigestível em detergente neutro & 2,96 & 3,54 & 1,11 \\
Proteína indigestível em detergente ácido & 0,47 & 0,81 & 0,81 \\
Extrato etéreo & 4,31 & 4,06 & 2,33 \\
Carboidratos totais & 72,41 & 85,31 & 45,75 \\
Fibra em detergente neutro & 68,91 & 20,08 & 14,92 \\
Fibra em detergente ácido & 41,71 & 6,21 & 19,47 \\
Fibra em detergente neutro corrigida para cinzas e proteína & 64,43 & 16,2 & 13,57 \\
Carboidratos não-fibrosos & 3,5 & 65,23 & 30,83 \\
Nutrientes digestíveis totais & 56,16 & 83,63 & 74,62 \\
Lignina & 4,65 & 1,98 & 5,75 \\
Cinzas & 9,85 & 1,16 & 6,41 \\
Matéria Orgânica & 90,15 & 98,84 & 93,59 \\
\hline
\end{tabular}

Fonte: Elaboração dos autores. 
Tabela 2. Composição nutricional dos concentrados.

\begin{tabular}{lcc}
\hline \multicolumn{1}{c}{ Ingredientes (\%MN) } & \multicolumn{2}{c}{ Nível de PB (\%MS do concentrado) } \\
\cline { 2 - 3 } \multicolumn{1}{c}{ Composição nutricional (\%MS) } & $\mathbf{1 4 \%} \mathbf{~ P B}$ & $\mathbf{1 8 \%} \mathbf{P B}$ \\
\hline Fubá de milho & 94,42 & 84,77 \\
Farelo de soja & 4,5 & 14,23 \\
Ureia & 1,08 & 1,00 \\
\hline \multicolumn{1}{c}{ Matéria seca (\%) } & 84,23 & 86,16 \\
Proteína bruta & 14,57 & 17,69 \\
Proteína indigestível em detergente neutro & 0,61 & 0,97 \\
Proteína indigestível em detergente ácido & 0,56 & 0,64 \\
Extrato etéreo & 4,14 & 4,45 \\
Carboidratos totais & 79,8 & 75,96 \\
Fibra em detergente neutro & 15,23 & 18,01 \\
Fibra em detergente ácido & 6,35 & 7,08 \\
Fibra em detergente neutro corrigida para cinzas e proteína & 13,84 & 16,68 \\
Carboidratos não-fibrosos & 64,57 & 57,95 \\
Nutrientes digestíveis totais & 86,61 & 85,41 \\
Lignina & 1,04 & 1,26 \\
Cinzas & 1,49 & 1,9 \\
Matéria Orgânica & 98,51 & 98,1 \\
\hline
\end{tabular}

Fonte: Elaboração dos autores.

As estimativas do consumo e da digestibilidade foram realizadas a partir da produção de matéria seca fecal mediante o uso do indicador externo LIPE®, utilizando-se diariamente uma capsula (500 mg/dia/vaca) fornecida a partir do $6^{\circ}$ dia de cada período experimental, por via oral juntamente com o concentrado e para os animais do nível zero (controle), a capsula foi introduzida diretamente na boca do animal.

As fezes foram coletadas nos últimos 5 dias de cada período experimental, diretamente da ampola retal. Foi feita uma amostra composta por animal, no qual foi retirada uma subamostra em torno de 800 $\mathrm{g}$ de fezes, pesadas, identificadas, acondicionadas em bandejas e submetidas à pré-secagem em estufa de ventilação forçada a $60{ }^{\circ} \mathrm{C}$ durante 120 horas, tempo suficiente para que o material apresentasse consistência quebradiça, permitindo sua moagem. Em seguida, as amostras foram novamente pesadas e trituradas em moinho tipo Willey em peneira com malha de $1 \mathrm{~mm}$ e uma porção em torno de $50 \mathrm{~g}$ de fezes moídas de cada animal foi acondicionada em potes plásticos hermeticamente fechados para posteriores análises. A determinação da concentração de LIPE® nas amostras de fezes foi realizada utilizando espectrofotômetro Infravermelho FTIV modelo VARIAN 800. Foi realizada a incubação in vitro para determinação dos coeficientes de digestibilidade da matéria seca do suplemento e do pasto, segundo metodologia de Tilley e Terry (1963). O consumo do capim Tanzânia foi estimado indiretamente em função da digestibilidade dos alimentos e da produção fecal, pela seguinte fórmula descrita por Lippke (2002):

Consumo $(\mathrm{kg}$ de MS/dia) = Produção fecal $(\mathrm{kg}$ de $\mathrm{MS} /$ dia) / (1 - digestibilidade aparente)

Em que a produção fecal pode ser determinada por meio do indicador externo LIPE® através da seguinte fórmula descrita por Saliba (2005):

$\mathrm{PF}(\mathrm{kg})=(\mathrm{LIPE} \AA$ fornecido $(\mathrm{g}) \times 100) /(\mathrm{Ai} /$ MS fecal) 
Onde PF = Produção fecal; Ai = Relação logarítmica das intensidades de absorção das bandas dos comprimentos de onda a $1050 \mathrm{~cm}^{-1} / 1650 \mathrm{~cm}^{-1}$ calculado através da fórmula: $\mathrm{Ai}=\mathrm{A} 1050 / \mathrm{A} 1650$, sendo que: $\mathrm{A}=\log \mathrm{Io} / \mathrm{I}$, onde, Io $>$ intensidade e $\mathrm{I}<$ intensidade. $\mathrm{MS}=$ matéria seca.

As ordenhas eram feitas manualmente, duas vezes ao dia (ás 7:30h e ás $15: 30$ h) e a produção de leite foi avaliada no $10^{\circ}, 11^{\circ}$ e $12^{\circ}$ dias de cada período experimental. Nos $10^{\circ}$ e $12^{\circ}$ dias de cada período, foram coletadas amostras de leite e de sangue. As amostras de leite foram obtidas nas ordenhas da manhã e tarde, compostas por animal e acondicionadas em frascos plásticos para em seguida serem determinados os teores de proteína, gordura, lactose e extrato seco total, em aparelho apropriado (Milk Analyser Lactoscan). O cálculo da produção de leite corrigida para $4 \%$ de gordura foi obtido pela fórmula do NRC (2001):

$$
\mathrm{PLC}=(0,4 \times \mathrm{PL})+(15 \times(\mathrm{PL} \times \mathrm{GOR})
$$

Em que, PLC = produção de leite corrigida para $4 \%$ de gordura, em $\mathrm{kg}$ por dia; $\mathrm{PL}=$ produção de leite, em kg/dia; GOR = produção de gordura em $\mathrm{kg}$ por dia $(\mathrm{GOR}=\mathrm{PL} \times \%$ GOR $)$, em que \% GOR é a porcentagem de gordura do leite.

As coletas de sangue foram feitas através de punção na veia mamária, por meio de tubos de vacutainer logo após a ordenha da manhã e 4 horas após a oferta do concentrado. Imediatamente, os tubos foram submetidos à centrifugação por 15 minutos a 3.500 rotações por minuto (RPM) para a obtenção do plasma. Este foi acondicionado em tubos do tipo ependorf e congelado a $-10^{\circ} \mathrm{C}$ para a determinação das concentrações de NUP. As determinações dos teores de NUP foram efetuadas utilizando-se o Kit Doles (Ureia 500), seguindo orientações técnicas do fabricante. As leituras das concentrações foram realizadas através do analisador bioquímico Thermo Plate Analyzer.

Foram feitas amostragens dos concentrados e do pasto durante o início e meio (aos 24 dias) do experimento. Para coleta do pasto, antes da entrada dos animais nos piquetes, foi utilizado um quadrado metálico de $1 \mathrm{~m}^{2}$ lançado aleatoriamente em 4 áreas/ piquete, com corte a $40 \mathrm{~cm}$ do solo, para em seguida serem feitas as análises bromatológicas. As amostras de pasto e concentrado foram secas em estufa a 65 ${ }^{\circ} \mathrm{C}$, moídas em peneiras de $2 \mathrm{~mm}$ e armazenadas. As análises laboratoriais para determinação da composição da pastagem e do concentrado em matéria seca (MS), proteína bruta (PB), extrato etéreo (EE), fibra em detergente neutro (FDN), fibra em detergente ácido (FDA), proteína insolúvel em detergente neutro (PIDN) e proteína insolúvel em detergente ácido (PIDA) foram realizadas de acordo com metodologias descritas por Silva e Queiroz (2002). Os carboidratos totais foram calculados segundo Sniffen et al. (1992), em que: $\mathrm{CT}=100$ - ( $\%$ de $\mathrm{PB}+\%$ de $\mathrm{EE}+\%$ de cinzas $)$. Os teores de CNF foram calculados como proposto por Mertens (1997): CNF $=100-[(\% \mathrm{~PB}+\% \mathrm{FDN}+$ $\% \mathrm{EE}+\%$ Cinzas) $]$. Os nutrientes digestíveis totais (NDT) foram calculados segundo Weiss (1999), pela seguinte equação: NDT $(\%)=$ PBD + FDND + CNFD + 2,25 EED, em que: PBD = proteína bruta digestível; FDND = fibra em detergente neutro digestível; $\mathrm{CNFD}=$ carboidratos não fibrosos digestíveis; e EED = extrato etéreo digestível. Os valores de PBD, FDND, CNFD e EED foram estimados segundo as equações descritas pelo NRC (2001): PBD (para alimentos volumosos) $=$ PB $\mathrm{x} \operatorname{Exp}(-1,2 \mathrm{x}(\mathrm{PIDA} / \mathrm{PB})$; e PBD (para alimentos concentrados $)=\mathrm{PB} \times[1-(0,4 \times \mathrm{PIDA} / \mathrm{PB})]$; FDND $=0,75 \times($ FDN-L $) \times\left[1-(\mathrm{L} / \mathrm{FDN})^{0,667}\right]$, onde $\mathrm{L}=$ lignina; $\mathrm{CNFD}=0,98 \times \mathrm{CNF}$. Todas as análises foram realizadas no Laboratório de Nutrição Animal do Departamento de Zootecnia da Universidade Federal de Sergipe.

A análise das variáveis foi realizada para os dois quadrados latinos (C14 e C18) individualmente. O modelo estatístico incluiu efeitos de tratamento (níveis de concentrado), animal e período. As análises estatísticas foram realizadas utilizandose o Sistema de Análises Estatísticas e Genéticas 
- SAEG (UFV, 1997), a 5\% de significância pelo teste Tukey. Para comparação e verificação de existência de interação entre os resultados obtidos para os quadrados latinos, procedeu-se à análise de variância, em esquema fatorial 4x2 (quatro níveis de concentrado e dois de PB).

\section{Resultados e Discussão}

As médias de consumo de nutrientes de cada grupo (C14 e C18) e o resultado das comparações feitas entre si estão apresentados na tabela 3. Ao serem comparados entre si, os grupos C14 e C18 não apresentaram diferenças significativas $(\mathrm{P}>0,05)$ de consumos de MS (kg/dia e \% peso vivo (PV)), FDN (kg/dia e \%PV), EE e NDT. Contudo, o consumo de $\mathrm{PB}$ foi maior $(\mathrm{P}<0,05)$ quando os níveis de PB aumentaram no concentrado, em decorrência do maior teor deste nutriente na dieta. Houve diminuição $(\mathrm{P}<0,05)$ nos consumos de CNF (de 1,54 para 1,44\%) e CT (de 8,21 para 8,05\%), devido aos menores teores desses nutrientes nas rações com $18 \%$ de PB (Tabela 2).

Foram observados aumentos significativos $(\mathrm{P}<0,05)$ nos consumos de MS, expressos em kg/ dia e \% PV, à medida que foram fornecidos os concentrados tanto no grupo $\mathrm{C} 14$ quanto no grupo C18. Bargo et al. (2003) compilaram dados de mais de 20 experimentos internacionais e demonstraram que o aumento no fornecimento de concentrado eleva o consumo total de matéria seca em vacas leiteiras em pastejo. Teixeira et al. (2011) constataram aumento de $45 \%$ no consumo de MS com a inclusão de concentrado na dieta. Os consumos de MS com médias de 2,23 e 2,38\% do PV nos diferentes níveis de PB no concentrado, observados neste trabalho, foram próximos aos encontrados por Silva et al. (2009) com 2,72 e 2,74\% e por Aroeira, Martins e Cóser (2004), com 2,3 e 2,8\% do PV, nos meses de estação chuvosa.
Os consumos de PB (kg/dia e \% PV), EE, CT e $\mathrm{CNF}$ foram maiores $(\mathrm{P}<0,05)$ quando utilizados os mais altos níveis de concentrado na dieta para animais de cada grupo (C14 e C18), o que pode ser explicado pelo aumento do consumo de MS. $\mathrm{O}$ aumento dos consumos de NDT, em ambos os grupos, está associado principalmente, ao maior consumo de CNF e à maior participação de concentrado na dieta.

Houve diminuição $(\mathrm{P}<0,05)$ nos consumos de FDN de 6,95 para $6,27 \mathrm{~kg} /$ dia, à medida que foram fornecidos os concentrados. Este fato pode ser explicado devido ao consumo diário de capim Tanzânia ter diminuído $(\mathrm{P}<0,05)$ com o aumento no nível de concentrado na dieta, variando de 10,09 a 8,07 kg de MS/dia gerando, consequentemente, menor consumo de FDN. Esta observação está de acordo com a teoria do efeito substitutivo, em que o animal consome todo o concentrado diminuindo seu consumo em forragem (BARGO et al., 2003), devido principalmente, a um limite fisiológico em que ocorre o atendimento de suas exigências nutricionais provocando saciedade.

Mertens (1985) sugeriu que o consumo de MS em vacas leiteiras é ótimo para consumos de FDN de 1,2 $\pm 0,1 \%$ do PV. Neste trabalho, os valores médios encontrados de consumos de FDN foram de 6,66 e $6,60 \mathrm{~kg} / \mathrm{dia}$ para as rações de 14 e $18 \%$ de $\mathrm{PB}$, respectivamente, representando 1,33 e 1,42\% do PV, valores acima dos sugeridos por Mertens (1985). Porém, Sousa et al. (2008) citaram que a média geral para o consumo de FDN encontrada na literatura nacional é de $1,6 \%$ do PV, ou seja, valor acima do encontrado nesta pesquisa. Lima, Berchielli e Nogueira (2001), avaliando o consumo de vacas leiteiras em pastagem de capim Tanzânia, também estimaram o consumo de FDN acima de 1,2\% do PV. Euclides et al. (2000) encontraram consumos de FDN entre 1,46 e 1,82\% do PV em pastagem de Brachiaria brizantha. 
Tabela 3. Consumos de nutrientes obtidos em função de níveis de concentrado e de proteína bruta na matéria seca em vacas leiteiras sob pastejo de capim Tanzânia.

\begin{tabular}{|c|c|c|c|c|c|c|c|c|c|c|}
\hline \multirow[t]{2}{*}{ Item } & \multicolumn{3}{|c|}{$\mathrm{NC}^{*}$} & \multicolumn{3}{|c|}{$\% \mathrm{~PB}$} & \multirow[b]{2}{*}{ CV (\%) } & \multicolumn{3}{|c|}{ Probabilidade } \\
\hline & 0 & 1 & 3 & 5 & 14 & 18 & & $\mathrm{NC}$ & PB & I \\
\hline MS, kg/dia & 10,09 & 10,44 & 11,47 & 12,33 & 11,15 & 11,02 & 2,60 & 0,00 & n.s & n.s \\
\hline MS, \%PV & 2,07 & 2,18 & 2,37 & 2,60 & 2,23 & 2,38 & 9,23 & 0,00 & n.s & n.s \\
\hline MS do pasto, $\mathrm{kg} / \mathrm{dia}$ & 10,09 & 9,59 & 8,91 & 8,07 & 9,25 & 9,08 & 3,15 & 0,00 & n.s & n.s \\
\hline MS do pasto, \%PV & 2,07 & 2,00 & 1,84 & 1,70 & 1,85 & 1,96 & 9,56 & 0,00 & n.s & n.s \\
\hline $\mathrm{PB}, \mathrm{kg} / \mathrm{dia}$ & 1,35 & 1,42 & 1,61 & 1,77 & 1,51 & 1,56 & 2,52 & 0,00 & 0,00 & n.s \\
\hline $\mathrm{PB}, \% \mathrm{PV}$ & 0,27 & 0,29 & 0,33 & 0,37 & 0,30 & 0,33 & 9,18 & 0,00 & 0,00 & n.s \\
\hline FDN, kg/dia & 6,95 & 6,75 & 6,57 & 6,27 & 6,66 & 6,60 & 3,00 & 0,00 & n.s & n.s \\
\hline FDN, \%PV & 1,42 & 1,40 & 1,36 & 1,32 & 1,33 & 1,42 & 9,44 & n.s & n.s & n.s \\
\hline $\mathrm{EE}$ & 0,43 & 0,45 & 0,49 & 0,53 & 0,47 & 0,47 & 2,61 & 0,00 & n.s & n.s \\
\hline $\mathrm{CNF}$ & 0,35 & 0,85 & 1,87 & 2,89 & 1,54 & 1,44 & 0,67 & 0,00 & 0,00 & 0,00 \\
\hline $\mathrm{CT}$ & 7,31 & 7,61 & 8,44 & 9,16 & 8,21 & 8,05 & 2,57 & 0,00 & 0,03 & n.s \\
\hline NDT & 5,67 & 6,12 & 7,20 & 8,19 & 6,84 & 6,75 & 2,38 & 0,00 & $\mathrm{n} . \mathrm{s}$ & n.s \\
\hline Item & & $\mathrm{NC} 1$ & $\% \mathrm{~PB}^{*}$ & & & & & & & \\
\hline & 0 & 1 & 3 & 5 & CV $(\%)$ & $\mathrm{R}^{2}$ & & $\mathrm{Eq}$ & & \\
\hline MS, kg/dia & 10,05 & 10,51 & 11,49 & 12,54 & 2,63 & 0,94 & & $=0,4966^{*} 1$ & $+10,03$ & \\
\hline MS, \%PV & 2,00 & 2,10 & 2,28 & 2,54 & 4,02 & 0,51 & & $=0,1051 * \mathrm{~N}$ & $+1,997$ & \\
\hline MS do pasto, $\mathrm{kg} / \mathrm{dia}$ & 10,05 & 9,67 & 8,96 & 8,32 & 3,18 & 0,88 & & $=-0,3457 *$ & $+10,0$ & \\
\hline MS do pasto, \%PV & 2,00 & 1,94 & 1,77 & 1,68 & 3,57 & 0,35 & & $=-0,0652 *$ & $+1,99$ & \\
\hline $\mathrm{PB}, \mathrm{kg} / \mathrm{dia}$ & 1,35 & 1,42 & 1,57 & 1,73 & 2,60 & 0,95 & & $=0,0763 * \mathrm{~N}$ & $+1,347$ & \\
\hline $\mathrm{PB}, \% \mathrm{PV}$ & 0,26 & 0,28 & 0,31 & 0,35 & 4,06 & 0,57 & & $=0,0165^{*} \mathrm{~N}$ & $+0,268$ & \\
\hline $\mathrm{FDN}, \mathrm{kg} / \mathrm{dia}$ & 6,93 & 6,79 & 6,56 & 6,38 & 3,04 & 0,62 & & $=-0,11 * \mathrm{NC}$ & 6,9157 & \\
\hline FDN, \%PV & 1,38 & 1,36 & 1,30 & 1,29 & 3,66 & - & & & & \\
\hline $\mathrm{EE}$ & 0,43 & 0,45 & 0,49 & 0,53 & 2,65 & 0,93 & & $=0,02 * \mathrm{NC}$ &, 4325 & \\
\hline $\mathrm{CNF}$ & 0,35 & 0,88 & 1,94 & 3,01 & 0,66 & 0,99 & & $=0,5318 * \mathrm{~N}$ & $+0,351$ & \\
\hline $\mathrm{CT}$ & 7,28 & 7,67 & 8,51 & 9,39 & 2,59 & 0,95 & & $=0,4218 * \mathrm{~N}$ & $+7,267$ & \\
\hline NDT & 5,64 & 6,16 & 7,22 & 8,32 & 2,41 & 0,98 & & $=0,5353^{*} \mathrm{~N}$ & $+5,636$ & \\
\hline Item & & $\mathrm{NC} 1$ & $\% \mathrm{~PB}^{*}$ & & & & & & & \\
\hline & 0 & 1 & 3 & 5 & $\mathrm{CV}(\%)$ & $\mathrm{R}^{2}$ & & Equ & & \\
\hline MS, kg/dia & 10,13 & 10,37 & 11,45 & 12,12 & 2,15 & 0,88 & & $=0,4168 * \mathrm{~N}$ & $+10,08$ & \\
\hline MS, \%PV & 2,13 & 2,25 & 2,47 & 2,67 & 3,77 & 0,58 & & $=0,1075^{*} \mathrm{~N}$ & $+2,143$ & \\
\hline MS do pasto, $\mathrm{kg} / \mathrm{dia}$ & 10,13 & 9,51 & 8,87 & 7,81 & 2,61 & 0,90 & & $=-0,4447 * 1$ & $+10,0$ & \\
\hline MS do pasto, \%PV & 2,13 & 2,06 & 1,91 & 1,72 & 3,46 & 0,53 & & $=-0,0822 * 1$ & $+2,14$ & \\
\hline $\mathrm{PB}, \mathrm{kg} / \mathrm{dia}$ & 1,36 & 1,43 & 1,64 & 1,81 & 2,03 & 0,95 & & $=0,0927 * \mathrm{~N}$ & 1,354 & \\
\hline $\mathrm{PB}, \% \mathrm{PV}$ & 0,28 & 0,31 & 0,35 & 0,39 & 3,92 & 0,75 & & $=0,0225 * \mathrm{~N}$ & $+0,287$ & \\
\hline FDN, kg/dia & 6,98 & 6,71 & 6,57 & 6,16 & 2,47 & 0,69 & & $=-0,1513 * 1$ & $+6,94$ & \\
\hline FDN, \%PB & 1,47 & 1,45 & 1,42 & 1,35 & 3,49 & - & & & & \\
\hline $\mathrm{EE}$ & 0,43 & 0,44 & 0,49 & 0,52 & 2,14 & 0,90 & & $=0,0192 * \mathrm{~N}$ & $+0,434$ & \\
\hline $\mathrm{CNF}$ & 0,35 & 0,83 & 1,80 & 2,77 & 0,57 & 0,99 & & $=0,4837 * \mathrm{~N}$ & $+0,353$ & \\
\hline $\mathrm{CT}$ & 7,33 & 7,54 & 8,38 & 8,93 & 2,13 & 0,90 & & $=0,3324 * \mathrm{~N}$ & $+7,302$ & \\
\hline NDT & 5,69 & 6,08 & 7,18 & 8,06 & 1,97 & 0,97 & & $=0,4861 * \mathrm{~N}$ & $-5,663^{\circ}$ & \\
\hline
\end{tabular}

MS: matéria seca; PB: proteína bruta; FDN: fibra em detergente neutro; EE: extrato etéreo; CNF: carboidratos não fibrosos; CT: carboidratos totais; NDT: nutrientes digestíveis totais; n.s = não-significativo $(\mathrm{P}>0,05) . \mathrm{CV}$ : coeficiente de variação $(\%)$. NC: níveis de concentrado; PB: proteína bruta; I: interação entre nível de concentrado e proteína bruta; $\mathrm{R}^{2}$ : coeficientes de determinação; *: $\mathrm{kg} / \mathrm{animal} / \mathrm{dia}$.

Fonte: Elaboração dos autores. 
Houve efeito de interação entre o consumo de CNF, em kg/animal/dia, e o teor de $\mathrm{PB}(\mathrm{P}<0,05)$ (Tabela 3). No desdobramento das interações, o consumo de CNF aumentou com o consumo de concentrado, porém o consumo de CNF reduziu com o aumento do teor de $\mathrm{PB}$, em virtude da maior utilização de farelo de soja para elevar o nível de PB do concentrado, reduzindo o suprimento de CNF em detrimento da PB (Tabela 4). Estes resultados corroboram com os encontrados por Silva et al. (2009) e por Obeid et al. (2007), em que o consumo de CNF decresceu linearmente com a elevação dos níveis de $\mathrm{PB}$ na dieta.

Tabela 4. Consumo de carboidratos não fibrosos (CCNF), em kg/animal/dia, nos diversos níveis de concentrado e proteína bruta em vacas leiteiras sob pastejo de capim Tanzânia no período das águas.

\begin{tabular}{ccccc}
\hline \%PB no concentrado & \multicolumn{4}{c}{ Níveis de concentrado $(\mathrm{kg} /$ animal $/$ dia $)$} \\
\hline & 0 & 1 & 3 & 5 \\
\cline { 2 - 5 } 14 & 0,35 & 0,88 & 1,95 & 3,01 \\
18 & 0,35 & 0,83 & 1,81 & 2,77 \\
\hline
\end{tabular}

$\% \mathrm{~PB}=$ teor de proteína bruta na matéria seca do concentrado.

Fonte: Elaboração dos autores.

Na Tabela 5, constam as médias dos coeficientes de digestibilidade aparente dos componentes nutritivos, suas respectivas equações de regressão e os coeficientes de determinação $\left(\mathrm{R}^{2}\right)$ e de variação (CV \%) para os diversos níveis de concentrado e proteína bruta. Ao serem comparados os grupos C14 e C18 entre si, observou-se que os níveis de $\mathrm{PB}$ não influenciaram $(\mathrm{P}>0,05)$ os coeficientes de digestibilidade aparente da MS, PB, FDN, EE e CT, apresentando valores de: 65,97 a $65,91 \% ; 73,51$ a $75,08 \%$; 62,04 a 65,01\%; 46,63 a 46,21\% e 72,73 a $73,04 \%$, respectivamente.

Obeid et al. (2007), também não observaram influência dos níveis de PB das dietas sobre as digestibilidades aparentes totais de MS, EE, FDN e CNF, provavelmente, em virtude da ausência de efeito dos níveis de PB sobre o consumo de MS. Esses resultados diferem de outros encontrados na literatura, em que maiores coeficientes de digestibilidade são gerados em maiores níveis de concentrado e de PB nas dietas. Pereira et al.
(2005), trabalhando com níveis crescentes de PB na dieta de vacas leiteiras mestiças $(12,7$ a $16,9 \%$ da MS total da dieta), observaram efeito linear positivo dos níveis de PB sobre as digestibilidades da MS, $\mathrm{PB}$ e FDN.

Houve aumentos $(\mathrm{P}<0,05)$ nos coeficientes de digestibilidade aparente da MS das dietas dos grupos C14 e C18 (individualmente) à medida que foram fornecidos os concentrados, sendo os maiores valores verificados para os níveis mais elevados de suplementação. Este fato pode ser explicado pela redução observada no consumo de FDN e aumento no consumo de CNF, o que melhorou o ambiente ruminal ao fornecer um aporte maior de nutrientes prontamente fermentáveis aos microrganismos ruminais. Valadares Filho et al. (2000), trabalhando com níveis crescentes de concentrado na dieta de vacas em lactação, afirmaram que geralmente ocorre aumento linear na digestibilidade da matéria seca, com redução do conteúdo menos digestível da FDN e aumento nos teores de CNF da dieta. 
Tabela 5. Coeficientes médios de digestibilidade aparente (\%) nos diversos níveis de concentrado e proteína bruta em vacas leiteiras sob pastejo de capim Tanzânia no período das águas.

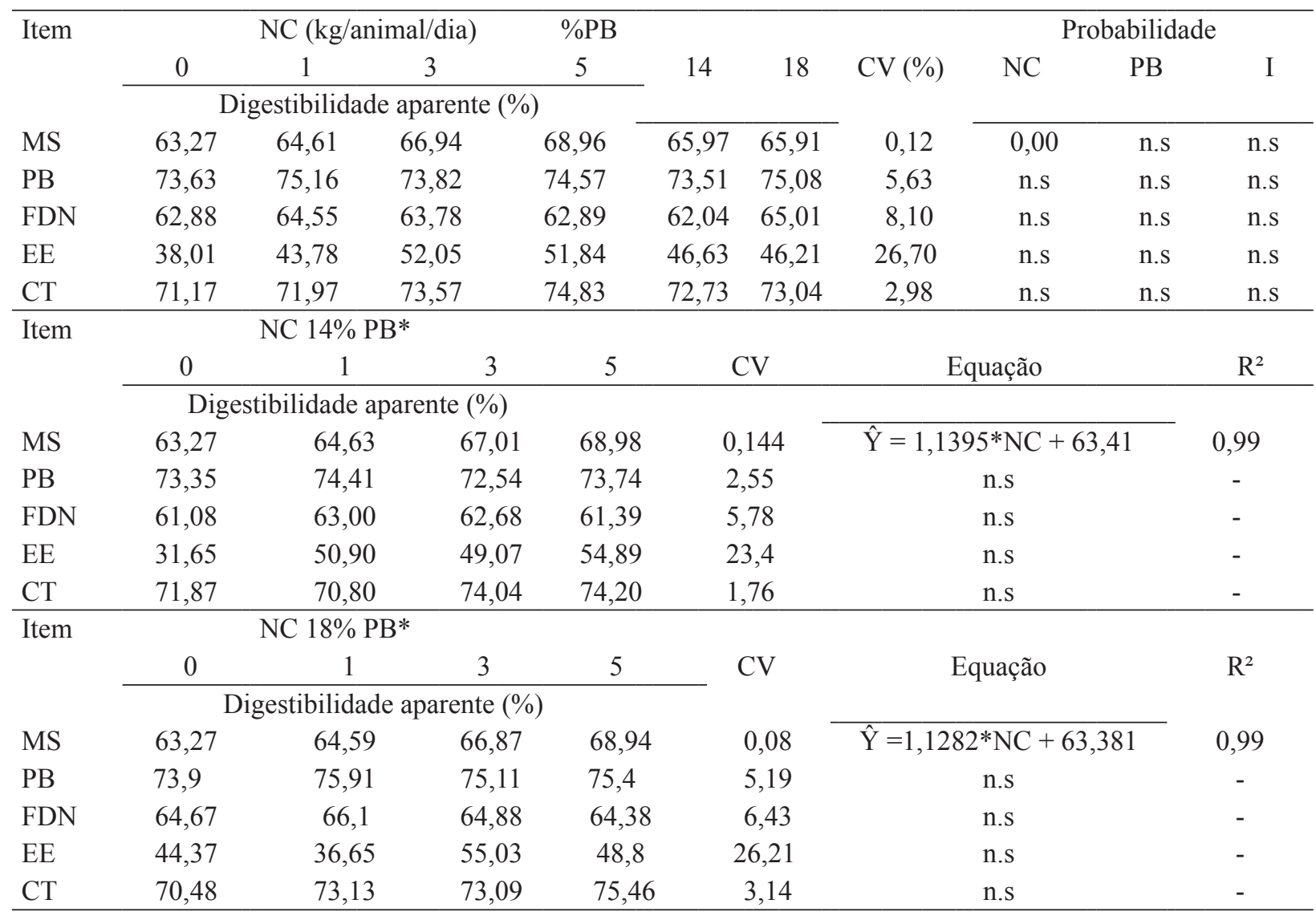

MS: matéria seca; PB: proteína bruta; FDN: fibra em detergente neutro; EE: extrato etéreo; CT: carboidratos totais; n.s = não significativo $(\mathrm{P}>0,05)$. CV: coeficiente de variação (\%). NC: níveis de concentrado; PB: proteína bruta; I: interação entre nível de concentrado e proteína bruta; $\mathrm{r}^{2}$ : coeficientes de determinação; *: $\mathrm{kg} / \mathrm{animal} / \mathrm{dia}$.

Fonte: Elaboração dos autores.

Os dados de produção e composição do leite das vacas leiteiras estudadas encontram-se na tabela 6. Independente do nível de concentrado e $\mathrm{PB}$, não foram observadas diferenças significativas $(\mathrm{P}>0,05)$ ao ser comparado os animais do grupo $\mathrm{C} 14$ com o grupo $\mathrm{C} 18$, na produção de leite, produção de leite corrigida para $4 \%$ de gordura e composição do leite (gordura, proteína, lactose e extrato seco total). Também não houve interação entre nível de concentrado e nível de PB.

Resultados semelhantes aos deste trabalho foram observados por Monteils et al. (2002) que não encontraram diferenças significativas na produção de leite quando compararam dietas com 13,0; 14,5 e $16,0 \%$ de PB. Pereira et al. (2009) estudaram o efeito da utilização de $6 \mathrm{~kg}$ de concentrado com diferentes teores de PB (15,2; 18,2 ou 21,1\%) para vacas mestiças em lactação sob pastejo rotacionado de capim-elefante, e não observaram diferenças entre os tratamentos, quanto ao consumo de MS na dieta total, produção de leite e os componentes: proteína, lactose e gordura, sugerindo o nível de $15,2 \%$ PB no concentrado como o mais indicado na alimentação de vacas leiteiras. Silva et al. (2009), ao compararem dietas contendo 11 e $13 \%$ de PB para vacas mestiças, não observaram diferenças significativas na produção de leite e componentes do leite, exceto lactose e extrato seco, que aumentaram 
com o nível de PB na dieta. Teixeira et al. (2010) concluíram que a utilização de maiores níveis de concentrado e proteína bruta não proporcionaram produção de leite mais elevadas, como aconteceu neste experimento.

As análises bromatológicas do capim Tanzânia utilizado neste experimento apresentou $13,43 \%$ de PB, 68,9\% de FDN e 56,1\% de NDT, características consideradas de boa qualidade do pasto. Esta composição foi semelhante à verificada por Rodrigues et al. (2010), que estudaram a composição química do capim Tanzânia e encontraram valores de 13,2 a $14,8 \%$ de $\mathrm{PB}$ e por Balsalobre et al. (2003) que avaliaram o pasto de capim Tanzânia irrigado sob três níveis de resíduo pós-pastejo e encontraram teores de NDT que variaram de 55,26 a 59,31\% e de FDN, de 64,52 a 66,15\%. Isto demonstra que a pastagem de capim Tanzânia local foi suficiente para manter a produção média de leite de $10,93 \mathrm{~kg} /$ dia, sem a necessidade de fornecer concentrados aos animais. Este fato possivelmente refletiu em baixa resposta em termos de produção de leite quando houve suplementação, associado ao potencial genético dos animais trabalhados (mestiços).

Tabela 6. Produção e composição do leite de vacas leiteiras sob pastejo em capim Tanzânia em função de níveis de concentrado e de proteína bruta.

\begin{tabular}{|c|c|c|c|c|c|c|c|c|c|c|}
\hline \multirow[b]{2}{*}{ Item } & \multicolumn{4}{|c|}{ NC (kg/animal/dia) } & \multicolumn{2}{|c|}{$\% \mathrm{~PB}$} & \multirow[b]{2}{*}{ CV $(\%)$} & \multicolumn{3}{|c|}{ Probabilidade } \\
\hline & 0 & 1 & 3 & 5 & 14 & 18 & & $\mathrm{NC}$ & $\mathrm{PB}$ & $\mathrm{I}$ \\
\hline Leite $\mathrm{kg} / \mathrm{vaca} / \mathrm{dia}$ & 10,93 & 11,09 & 11,94 & 13,4 & 11,7 & 11,98 & 19,26 & n.s & n.s & n.s \\
\hline Leite $(4 \% \mathrm{G}) \mathrm{kg} / \mathrm{dia}$ & 10,68 & 11,26 & 11,79 & 13,72 & 11,23 & 12,5 & 21,67 & n.s & n.s & n.s \\
\hline Gordura \% & 3,91 & 4,12 & 3,99 & 4,09 & 3,77 & 4,28 & 13,59 & n.s & n.s & n.s \\
\hline Proteína \% & 3,28 & 3,44 & 3,43 & 3,46 & 3,37 & 3,43 & 6,55 & n.s & n.s & n.s \\
\hline Lactose $\%$ & 4,92 & 5,16 & 5,14 & 5,19 & 5,05 & 5,15 & 6,53 & n.s & n.s & n.s \\
\hline \multirow[t]{2}{*}{ Extrato seco total \% } & 8,56 & 8,99 & 8,93 & 9,07 & 8,82 & 8,95 & 6,52 & n.s & n.s & n.s \\
\hline & \multicolumn{5}{|c|}{ NC $14 \%$ PB (kg/animal/dia) } & \multirow{3}{*}{$\begin{array}{c}\text { CV } \\
9,91\end{array}$} & & & & \\
\hline Item & 0 & 1 & 3 & & 5 & & \multicolumn{4}{|c|}{ Probabilidade } \\
\hline Leite $\mathrm{kg} / \mathrm{vaca} / \mathrm{dia}$ & 10,58 & 10,98 & \multicolumn{2}{|l|}{12,2} & 13,04 & & \multicolumn{4}{|c|}{ n.s } \\
\hline Leite $(4 \% \mathrm{G}) \mathrm{kg} / \mathrm{dia}$ & 10,12 & 10,88 & \multicolumn{2}{|c|}{11,57} & 12,34 & 9,05 & \multicolumn{4}{|c|}{ n.s } \\
\hline Gordura \% & 3,71 & 3,96 & \multicolumn{2}{|l|}{3,74} & 3,68 & 9,13 & \multicolumn{4}{|c|}{ n.s } \\
\hline Proteína \% & 3,26 & 3,4 & \multicolumn{2}{|l|}{3,35} & 3,48 & 4,72 & \multicolumn{4}{|c|}{ n.s } \\
\hline Lactose $\%$ & 4,89 & 5,11 & \multicolumn{2}{|l|}{5} & 5,22 & 4,7 & \multicolumn{4}{|c|}{ n.s } \\
\hline \multirow[t]{2}{*}{ Extrato seco total \% } & 8,51 & 8,9 & 8,76 & & 9,13 & 4,79 & & n.s & & \\
\hline & \multicolumn{5}{|c|}{ NC 18\% PB (kg/animal/dia) } & & & & & \\
\hline Item & 0 & 1 & \multicolumn{2}{|l|}{3} & 5 & CV $(\%)$ & \multicolumn{4}{|c|}{ Probabilidade } \\
\hline Leite $\mathrm{kg} / \mathrm{vaca} / \mathrm{dia}$ & 11,28 & 11,19 & \multicolumn{2}{|l|}{11,68} & 13,77 & 8,92 & \multicolumn{4}{|c|}{$\mathrm{n} . \mathrm{s}$} \\
\hline Leite $(4 \% \mathrm{G}) \mathrm{kg} / \mathrm{dia}$ & 11,24 & 11,64 & \multicolumn{2}{|l|}{12} & 15,1 & 19,27 & \multicolumn{4}{|c|}{ n.s } \\
\hline Gordura \% & 4,1 & 4,28 & \multicolumn{2}{|l|}{4,25} & 4,5 & 16,86 & \multicolumn{4}{|c|}{ n.s } \\
\hline Proteína \% & 3,3 & 3,47 & \multirow{2}{*}{\multicolumn{2}{|c|}{$\begin{array}{l}3,52 \\
5,28\end{array}$}} & 3,44 & 6,38 & \multicolumn{4}{|c|}{ n.s } \\
\hline Lactose $\%$ & 4,95 & 5,21 & & & 5,17 & 6,35 & \multicolumn{4}{|c|}{ n.s } \\
\hline Extrato seco total \% & 8,61 & 9,08 & 9,11 & & 9,01 & 6,19 & & n.s & & \\
\hline
\end{tabular}

Leite $(4 \% \mathrm{G})=$ produção corrigida para $4 \%$ de gordura. n.s = não-significativo $(\mathrm{P}>0,05)$. CV: coeficiente de variação $(\%)$. NC: níveis de concentrado; PB: proteína bruta; I: interação entre nível de concentrado e proteína bruta.

Fonte: Elaboração dos autores. 
A produção de leite (normal e corrigida para $4 \%$ de gordura) não foi influenciada $(\mathrm{P}>0,05)$ pelos níveis de suplementação tanto para o grupo de animais alimentados com concentrado contendo $14 \%$ e $18 \%$ de PB, individualmente (Tabela 6). A produção de leite a pasto neste experimento variou de 10,58 a 11,28, valores próximos ao encontrado por Santos et al. (2005), que observaram produções médias de leite de $11,1 \mathrm{~kg} / \mathrm{vaca} / \mathrm{dia}$ para os estádios de lactação de 91 a 180 dias, em vacas sob pastejo rotacionado de capim Tanzânia sem suplementação; e por Lima et al. (2004), que encontraram produções médias de $10,0 \mathrm{~kg}$ de leite/ dia para vacas mestiças (Holandês x Gir) mantidas em pastejo rotacionado de capim Tanzânia e adubado com $250 \mathrm{~kg} / \mathrm{ha}$./ano.

O teor de gordura do leite é fortemente influenciado pela relação volumoso:concentrado. Quando há aumento do concentrado da dieta, há maior produção de ácido propiônico, redução no pH ruminal e menor produção de acetato no rúmen, beneficiando as bactérias amilolíticas. Porém quando uma dieta é rica em volumoso, ocorre aumento no $\mathrm{pH}$ e beneficiamento da atividade das bactérias celulolíticas, o que gera maior produção de ácido acético, precursor da gordura do leite. No caso deste experimento, não houve influência $(\mathrm{P}>0,05)$ dos níveis de concentrado sobre a quantidade de gordura no leite, possivelmente devido ao efeito substitutivo do volumoso pelo concentrado, provocando redução no consumo de forragem. Também não foi observada influência $(\mathrm{P}>0,05)$ dos níveis de concentrado e de $\mathrm{PB}$ sobre a porcentagem de proteína, lactose e consequentemente, extrato seco total. Segundo González, Durr e Fontaneli (2001) e Peres (2000), o teor de proteína da dieta tem baixa influência na porcentagem de proteína no leite, independente da degradabilidade ruminal. Pereira et al. (2005) utilizando níveis crescentes de proteína bruta em dietas de vacas de leite, não encontraram efeito significativo no teor de proteína do leite. Da mesma forma, a lactose é um dos componentes mais estáveis do leite, com concentração em torno de 5\%. Resultados semelhantes foram encontrados por Costa et al. (2005) e Stelzer et al. (2009) e comprovam que a lactose é realmente o componente do leite que apresenta a menor variação com a alimentação.

Não foram observadas diferenças significativas $(\mathrm{P}>0,05)$ para os níveis de nitrogênio ureico no plasma (NUP), quando comparados os grupos C14 e C18 entre si, assim como os níveis de NUP não foram influenciados $(\mathrm{P}>0,05)$ pelos níveis de suplementação tanto do grupo $\mathrm{C} 14$ quanto do grupo $\mathrm{C} 18$, individualmente (Tabela 7). Esta não variação nos teores de NUP pode ter ocorrido devido à quantidade de proteína consumida, com médias de 1,51 e $1,56 \%$ de $\mathrm{PB}$ para os grupos C14 e C18 respectivamente, o que manteve níveis de NUP semelhantes entre os tratamentos. Além disso, é importante lembrar que ocorreu redução do consumo do pasto pelos animais à medida que houve o fornecimento de suplementos ocasionando efeito substitutivo, mantendo-se na faixa de $1,5 \%$ os valores de PB consumida e com isso provocando pouca variação sobre os valores de NUP. 
Tabela 7. Nitrogênio ureico no plasma de vacas leiteiras sob pastejo em capim Tanzânia em função de níveis de concentrado e de proteína bruta.

\begin{tabular}{|c|c|c|c|c|c|c|c|c|c|c|}
\hline \multirow{4}{*}{$\begin{array}{l}\text { NUP } \\
\text { Manhã } \\
\text { 4h após } \\
\text { alimentação }\end{array}$} & \multicolumn{4}{|c|}{$\mathrm{NC}$ (kg/animal/dia) } & \multicolumn{2}{|c|}{$\% \mathrm{~PB}$} & \multirow[b]{2}{*}{$\mathrm{CV}(\%)$} & \multicolumn{3}{|c|}{ Probabilidade } \\
\hline & 0 & 1 & 3 & 5 & 14 & 18 & & $\mathrm{NC}$ & $\mathrm{PB}$ & I \\
\hline & 12,65 & 12,22 & 11,99 & 12,83 & 12,17 & 12,68 & 14,23 & n.s & n.s & n.s \\
\hline & 13,95 & 13,84 & 14,49 & 14,89 & 13,9 & 14,69 & 14,58 & n.s & n.s & n.s \\
\hline & \multicolumn{6}{|c|}{ NC (14\% PB) (kg/animal/dia) } & & & & \\
\hline NUP & 0 & & 1 & 3 & & 5 & CV $(\%)$ & \multicolumn{3}{|c|}{ Probabilidade } \\
\hline Manhã & 12,6 & & 12,65 & 11,59 & & 11,82 & 8,85 & \multicolumn{3}{|c|}{ n.s } \\
\hline $\begin{array}{l}\text { 4h após } \\
\text { alimentação }\end{array}$ & 13,8 & & 14,48 & 13,02 & & 14,31 & 6,47 & \multicolumn{3}{|c|}{ n.s } \\
\hline \multicolumn{11}{|c|}{ NC (18\% PB) (kg/animal/dia) } \\
\hline NUP & 0 & & 1 & 3 & & 5 & CV $(\%)$ & \multicolumn{3}{|c|}{ Probabilidade } \\
\hline Manhã & 12,69 & & 11,78 & 12,39 & & 13,84 & 8,69 & \multicolumn{3}{|c|}{ n.s } \\
\hline $\begin{array}{l}\text { 4h após } \\
\text { alimentação }\end{array}$ & 14,1 & & 13,21 & 15,96 & & 15,48 & 7,44 & \multicolumn{3}{|c|}{ n.s } \\
\hline
\end{tabular}

NUP: nitrogênio ureico no plasma $(\mathrm{mg} / \mathrm{dL})$. n.s = não-significativo $(\mathrm{P}>0,05)$. CV: coeficiente de variação $(\%)$. NC: níveis de concentrado; PB: proteína bruta; I: interação entre nível de concentrado e proteína bruta.

Fonte: Elaboração dos autores.

Todos os valores de NUP analisados neste experimento, independente do nível de concentrado e de $\mathrm{PB}$, encontraram-se dentro da faixa normal, com variação de 13,02 a 15,96 mg/dL. De acordo com Butler, Calaman e Beam (1996); Broderik e Clayton (1997), os valores de NUP considerados adequados para vacas em lactação estão entre 7 e 19 $\mathrm{mg} / \mathrm{dL}$. Isso demonstra eficiência na utilização de nitrogênio, resultando em indicadores do equilíbrio ruminal entre nitrogênio e energia.

Ruas et al. (2000) trabalhando em condições brasileiras, encontraram níveis de ureia plasmática de $7 ; 10,8$ e $15,4 \mathrm{mg} / \mathrm{dL}$ de NUP para vacas alimentadas somente a pasto e suplementadas com 1 e $2 \mathrm{~kg}$ de concentrado, respectivamente. Lima et al. (2004), encontraram médias de NUP de 7,8 a $12,1 \mathrm{mg} / \mathrm{dL}$ para vacas mestiças mantidas em capim Tanzânia. Pereira et al. (2009) constataram valores de NUP de 11,5 e 12,2 e 14,4 mg/dL para dietas com 15,$2 ; 18,2$ e $21,1 \%$ de $\mathrm{PB}$, respectivamente. Segundo Oliveira et al. (2001), concentrações de NUP superiores a $19 \mathrm{mg} / \mathrm{dL}$ representam o limite para perdas de nitrogênio dietético, o que não foi observado nesta pesquisa.

Em uma análise econômica, observa-se que embora não tenha havido diferença significativa para as produções de leite, percebe-se numericamente, que os níveis crescentes de concentrado fornecido aos animais do $\mathrm{C} 14$ ocasionou aumento da produção de leite, com variação de 2,46 kg/vaca/dia, do nível 0 para $5 \mathrm{~kg} /$ dia de concentrado. Nos animais do grupo C18, também é perceptível um aumento de $2,49 \mathrm{~kg}$ de leite/vaca/dia ao passar do nível 0 para $5 \mathrm{~kg} / \mathrm{dia}$ de concentrado. Com relação ao comprometimento mínimo da receita do leite (CRL) com a alimentação animal (Tabela 8), houve variação de 6,95 a 29,29\%, do tratamento de $1 \mathrm{~kg}$ ao de $5 \mathrm{~kg}$ de concentrado em $\mathrm{C} 14$, ou seja, com o preço pago pelo $\mathrm{kg}$ do leite na propriedade de $\mathrm{R} \$ 0,93$, as produções de leite de 10,$98 ; 12,2$ e $13,04 \mathrm{~kg} / \mathrm{vaca} /$ dia e os custos das rações de 1,3 e $5 \mathrm{~kg}$ de $\mathrm{R} \$ 0,71 ; \mathrm{R} \$ 2,13$ e $\mathrm{R} \$ 3,55$, respectivamente, geraram uma receita líquida diária por animal de $\mathrm{R} \$ 9,5 ; \mathrm{R} \$ 9,21$ e R\$ 8,57. Da mesma forma ocorreu com o concentrado em $\mathrm{C} 18$, em que o CRL variou de 7,78 a $31,64 \%$ do tratamento de $1 \mathrm{~kg}$ ao de $5 \mathrm{~kg}$ de concentrado, em que as produções de 
leite de 11,$19 ; 11,68$ e $13,77 \mathrm{~kg} / \mathrm{vaca} /$ dia e os custos das rações de 1, 3 e $5 \mathrm{~kg}$ de $\mathrm{R} \$ 0,81$; $\mathrm{R}$ 2,43 e R\$ 4,05 , respectivamente, geraram uma receita líquida diária de $\mathrm{R} \$ 9,59$; $\mathrm{R} \$ 8,43$ e $\mathrm{R} \$ 8,75$ por animal. Isto na prática foi economicamente inviável para o produtor, pois quando os animais foram mantidos somente a pasto, as produções de leite geraram maior receita líquida (média de $\mathrm{R} \$ 9,96$ ) e ficaram próximas às produções de leite quando foram fornecidos os suplementos. Isto realça a importância de se atingir um equilíbrio entre produção e seus custos, pois produzir muito não significa produzir com eficiência.

Tabela 8. Produção de leite, Preço do leite, receita do leite, custos das rações e comprometimento da receita do leite (CRL) em função dos níveis de concentrado (NC) e proteína bruta ofertado em kg/dia.

\begin{tabular}{|c|c|c|c|c|c|c|c|c|}
\hline \multirow{2}{*}{ Variáveis } & \multicolumn{4}{|c|}{ NC (14\% PB) } & \multicolumn{4}{|c|}{ NC (18\% PB) } \\
\hline & 0 & 1 & 3 & 5 & 0 & 1 & 3 & 5 \\
\hline Produção de leite (kg/vaca/dia) & 10,58 & 10,98 & 12,2 & 13,04 & 11,28 & 11,19 & 11,68 & 13,77 \\
\hline Preço do leite $(\mathrm{R} \$)$ & 0,93 & 0,93 & 0,93 & 0,93 & 0,93 & 0,93 & 0,93 & 0,93 \\
\hline Receita do leite (R\$) & 9,83 & 10,21 & 11,34 & 12,12 & 10,49 & 10,4 & 10,86 & 12,8 \\
\hline Custos das rações (R\$) & 0,00 & 0,71 & 2,13 & 3,55 & 0,00 & 0,81 & 2,43 & 4,05 \\
\hline CRL $(\%)$ & 0,00 & 6,95 & 18,78 & 29,29 & 0,00 & 7,78 & 22,37 & 31,64 \\
\hline Receita líquida (R\$) & 9,83 & 9,5 & 9,21 & 8,57 & 10,49 & 9,59 & 8,43 & 8,75 \\
\hline
\end{tabular}

Fonte: Elaboração dos autores.

Na propriedade trabalhada, o produtor recebe o pagamento do leite com base no volume produzido e sólidos totais (gordura e proteína do leite), ficando evidente as desvantagens do uso de suplemento ao rebanho pesquisado independente do teor de PB (14 ou $18 \%$ ), já que a produção a pasto também manteve os percentuais dos sólidos gordura e proteína do leite dentro dos valores exigidos pelo laticínio local para o pagamento da bonificação, no qual deve conter teor mínimo de gordura e proteína de 3,5 e $3,0 \%$, respectivamente.

O manejo do rebanho leiteiro em sistema de pastejo rotacionado de capim Tanzânia sem suplementação, mostrou-se como o sistema de produção de leite mais viável e rentável na época das chuvas para vacas mestiças com produção média de $12 \mathrm{~kg}$ de leite/vaca/dia, nas condições deste experimento.

\section{Conclusão}

Diferentes níveis de concentrados $(0,1,3$, e $5 \mathrm{~kg} / \mathrm{vaca} / \mathrm{dia}$ ) e níveis de proteína bruta (4 e $18 \% \mathrm{~PB}$ ) na matéria seca total do concentrado influenciam linearmente o consumo de nutrientes em vacas leiteiras sob pastejo de capim Tanzania, no entanto, não influenciam os coeficientes médios de digestibilidade aparente, bem como a produção, composição do leite e teor de nitrogênio ureico no plasma.

\section{Referências}

AROEIRA, L. J. M.; MARTINS, C. E.; CÓSER, A. C. Sistemas alternativos para produção de leite e carne a pasto. In: MARTINS, C. E.; CÓSER, A. C.; ALENCAR, C. A. B. (Ed.). Sustentabilidade da pecuária de leite e de corte da Região do Leste Mineiro. Juiz de Fora: Embrapa Gado de Leite, 2004. p. 31-50. 
BALSALOBRE, M. A. A.; CORSI, M.; SANTOS, P. M.; VIEIRA, I.; CÁRDENAS, R. R. Composição química e fracionamento do nitrogênio e dos carboidratos do capim-tanzânia irrigado sob três níveis de resíduo póspastejo. Revista Brasileira de Zootecnia, Viçosa, MG, v. 32, n. 3, p. 519-528, 2003.

BARGO, F.; MULLER, L. D.; KOLVER, E. S.; DELAHOY, J. E. Invited review: Production and digestion of supplemented dairy cows on pasture. Journal of Dairy Science, Champaign, v. 86, n. 1, p. 1-42, 2003.

BRÂNCIO, P. A.; EUCLIDES, V. P. B.; NASCIMENTO JÚNIOR, D.; FONSECA, D. M.; ALMEIDA, R. G.; MACEDO, M. C. M.; BARBOSA, R. A. Avaliação de três cultivares de Panicum maximum Jacq. sob pastejo: disponibilidade de forragem, altura do resíduo póspastejo e participação de folhas, colmos e material morto. Revista Brasileira de Zootecnia, Viçosa, MG, v. 32, n. 1, p. 55-63, 2003.

BRODERIK, A. G.; CLAYTON, M. K. A statistical evaluation of animal and nutrition factors influencing concentrations of milk urea nitrogen. Journal of Dairy Science, Champaign, v. 80, n. 11, p. 2964-2971, 1997.

BRUN-LAFLEUR, L.; DELABY, L.; HUSSON, F.; FAVERDIN, P. Predicting energy $\mathrm{x}$ protein interaction on milk yield and milk composition in dairy cows. Journal of Dairy Science, Champaign, v. 93, n. 9, p. 4128-4143, 2010.

BUTLER, W. R.; CALAMAN, J. J.; BEAM, S. W. Plasma and milk urea nitrogen in relation to pregnancy rate in lactating dairy cattle. Journal of Animal Science, Champaign, v. 74, n. 4, p. 858-865, 1996.

CARVALHO, P. C. F.; DEWULF, A. K. M. Y.; MORAES, A.; BREMM, C.; TRINDADE, J. K.; LANG, C. R. Potencial do capim-quicuio em manter a produção e a qualidade do leite de vacas recebendo níveis decrescentes de suplementação. Revista Brasileira de Zootecnia, Champaign, v. 39, n. 9, p. 1866-1874, 2010.

CORDEIRO, C. F. A.; PEREIRA, M. L. A.; MENDONÇA, S. S.; ALMEIDA, P. J. P.; AGUIAR, L. V.; FIGUEIREDO, M. P. Consumo e digestibilidade total dos nutrientes e produção e composição do leite de vacas alimentadas com teores crescentes de proteína bruta na dieta contendo cana-de-açúcar e concentrados. Revista Brasileira de Zootecnia, Viçosa, MG, v. 36, n. 6, p. 21182126, 2007.

COSTA, M. G.; CAMPOS, J. M. S.; VALADARES FILHO, S. C.; VALADARES, R. F. D.; MENDONÇA, S. S.; SOUZA, D. P.; TEIXEIRA, M. P. Desempenho produtivo de vacas leiteiras alimentadas com diferentes proporções de cana-de-açúcar e concentrado ou silagem de milho na dieta. Revista Brasileira de Zootecnia, Viçosa, MG, v. 34, n. 6, p. 2437-2445, 2005.

DETMANN, E.; VALADARES FILHO, S. C.; HENRIQUES, L. T.; PINA, D. S.; PAULINO, M. F.; VALADARES, R. F. D.; CHIZZOTTI, M. L.; MAGALHÃES, K. A. Estimação da digestibilidade dos carboidratos não-fibrosos em bovinos utilizando-se o conceito de entidade nutricional em condições brasileiras. Revista Brasileira de Zootecnia, Viçosa, MG, v. 35, n. 4, p. 1479-1486, 2006.

EUCLIDES, V. P.; CARDOSO, E. G.; MACEDO, M. C. M.; OLIVEIRA, M. P. Consumo voluntário de Brachiaria decumbens cv. Basilisk e Brachiaria brizantha cv. Marandu sob pastejo. Revista Brasileira de Zootecnia, Viçosa, MG, v. 29, n. 6, p. 2200-2208, 2000. Suplemento 2.

GONZÁLEZ, F. H. D.; DÜRR, J. W.; FONTANELI, R. S. Uso do leite para monitorar a nutrição e o metabolismo de vacas leiteiras. Porto Alegre: Gráfica UFRGS, 2001. $77 \mathrm{p}$.

JONES-ENDSLEY, J. M.; CECAVA, M. J.; JOHNSON, T. R. Effects of dietary supplementation on nutrient digestion and the milk yield of intensively grazed lactating dairy cows. Journal of Dairy Science, Champaign, v. 80, n. 12, p. 3283-3292, 1997.

KALSCHEUR, K. F.; VANDERSALL, J. H.; ERDMAN, R. A.; KOHN, R. A.; RUSSEK-COHEN, E. Effects of dietary crude protein concentration and degradability on milk production responses of early, mid, and late lactation dairy cows. Journal of Dairy Science, Champaign, v. 82, n. 3, p. 545-554, 1999.

LANA, R. P. Nutrição e alimentação animal: mitos e realidades. 2. ed. Viçosa, MG: Editora UFV, 2007. 344 p.

LANZETTA, V. A. S.; REZENDE, A. S. C.; SALIBA, E. O. S.; LANA, A. M. Q.; RODRIGUEZ, N. M.; MOSS, P. C. B. Validação do Lipe ${ }^{\circledR}$ como método para determinar a digestibilidade dos nutrientes em equinos. Revista Brasileira de Zootecnia, Viçosa, MG, v. 38, n. 1, p. 6974, 2009.

LIMA, M. L. P.; BERCHIELLI, T. T.; LEME, P. R.; NOGUEIRA, J. R.; PINHEIRO, M. G. Concentração de nitrogênio uréico plasmático (NUP) e produção de leite de vacas mestiças mantidas em gramíneas tropicais sob pastejo rotacionado. Revista Brasileira de Zootecnia, Viçosa, MG, v. 33, n. 6, p. 1616-1626, 2004.

LIMA, M. L. P.; BERCHIELLI, T. T.; NOGUEIRA, J. R. Estimativa do consumo voluntário do capim-Tanzânia (Panicum maximum, Jacq. cv. Tanzânia) por vacas em lactação sob pastejo rotacionado. Revista Brasileira de Zootecnia, Viçosa, MG, v. 30, n. 6, p. 1919-1924, 2001. 
LIPPKE, H. Estimation of forage intake by ruminants on pasture. Crop Science, Madison, v. 42, n. 3, p. 869-872, 2002.

MERTENS, D. R. Creating a system for meeting the fiber requirements of dairy cows. Journal of Dairy Science, Champaign, v. 80, n. 7, p. 1463-1481, 1997.

Factors influencing feed intake in lactating cows: from theory to application using neutral detergente fiber. In: GA NUTRITION CONFERENCE, 46., 1985, Athens. Proceedings... Athens: University of Georgia, 1985. p. 1-18.

MONTEILS, V.; JURJANZ, S.; BLANCHART, G.; LAURENT, F. Nitrogen utilisation by dairy cows fed diets differing in crude protein level with a deficit in ruminal fermentable nitrogen. Reproduction Nutrition Development, Les Ulis, v. 42, n. 6, p. 545-557, 2002.

NATIONAL RESEARCH COUNCIL - NRC. Nutrient requirements of dairy cattle. 7. ed. Washington, D.C.: National Academy of Sciences, 2001. 381 p.

OBEID, J. A.; PEREIRA, O. G.; PEREIRA, D. H.; VALADARES FILHO, S. C.; CARVALHO, I. P. C.; MARTINS, J. M. Consumo e digestibilidades total e parcial de componentes nutritivos em bovinos de corte alimentados com dietas contendo diferentes níveis de proteína bruta. Revista Brasileira de Zootecnia, Viçosa, MG, v. 36, n. 4, p. 921-927, 2007.

OLIVEIRA, A. S.; VALADARES, R. F. D.; VALADARES FILHO, S. C.; CECON, P. R.; RENNÓ, L. N.; QUEIROZ, A. C.; CHIZZOTTI, M. L. Produção de proteína microbiana e estimativa das excreções de derivados de purinas e de ureia em vacas lactantes alimentadas com rações isoprotéicas contendo diferentes níveis de compostos nitrogênios não protéicos. Revista Brasileira de Zootecnia, Viçosa, MG, v. 30, n. 5, p. 16211629, 2001.

PEREIRA, F. R.; SATURNINO, H. M.; SALIBA, E. O. S.; GONÇALVES, L. C.; REIS, R. B.; MIRANDA, P. A. B.; MOURÃO, R. C.; SILVETRE, D. T.; CALDEIRA, P. N. S. Teores de proteína para vacas lactantes em pastejo de capim-elefante. Arquivo Brasileiro de Medicina Veterinária e Zootecnia, Belo Horizonte, v. 61, n. 5, p. 1139-1147, 2009.

PEREIRA, M. L. A.; VALADARES FILHO, S. C.; VALADARES, R. F. D.; CAMPOS, J. M. S.; LEÃO, M. I.; PEREIRA, C. A. R; PINA, D. S.; MENDONÇA, S. S. Consumo, digestibilidade aparente total, produção e composição do leite em vacas no terço inicial da lactação alimentadas com níveis crescentes de proteína bruta no concentrado. Revista Brasileira de Zootecnia, Viçosa, MG, v. 34, n. 3, p. 1029-1039, 2005.
PERES, J. R. O leite como ferramenta do monitoramento nutricional. In: GONZÁLEZ, F. H. D.; DÜRR, J. W.; FONTANELI, R. S. (Ed.). Uso do leite para monitorar a nutrição e o metabolismo de vacas leiteiras. Porto Alegre: Universidade Federal do Rio Grande do Sul, 2000. p. 30-45.

PINA, D. S.; VALADARES FILHO, S.C.; VALADARES, R. F. D.; CAMPOS, J. M. S.; DETMANN, E.; MARCONDES, M. I.; OLIVEIRA, A. S.; TEIXEIRA, R. M. A. Consumo e digestibilidade aparente total dos nutrientes, produção e composição do leite de vacas alimentadas com dietas contendo diferentes fontes de proteína. Revista Brasileira de Zootecnia, Viçosa, MG, v. 35, n. 4, p. 1543-1551, 2006.

RODRIGUES, L.; MEIRELLES, P. R. L.; GONÇALVES, H. C.; MARTINS, M.F.; MARQUES, R.O.; ARRUDA, G. M. M. F. Disponibilidade e composição química do capim-tanzânia, pastejado por caprinos. Veterinária $e$ Zootecnia, Botucatu, v. 17, n. 4, p. 585-595, 2010.

RUAS, J. R. M.; TORRES, C. A. A.; BORGES, L. E.; MARCATTI NETO, A.; MACHADO, G. V.; BORGES, A. M. Efeito da suplementação proteica a pasto sobre eficiência reprodutiva e concentração sanguínea de colesterol, glicose e ureia em vacas Nelore. Revista Brasileira de Zootecnia, Viçosa, MG, v. 29, n. 6, p. 20432050, 2000.

SALIBA, E. O. S. Uso de indicadores: passado, presente e futuro. In: TELECONFERÊNCIA SOBRE INDICADORES EM NUTRIÇÃO ANIMAL, 1., 2005, Belo Horizonte. Anais... Escola de Veterinária/UFMG, 2005. p. 04-22.

SANTOS, A. L.; LIMA, M. L. P.; BERCHIELLI, T. T.; LEME, P. R.; MALHEIROS, E. B.; NOGUEIRA, J. R.; PINHEIRO, M. G.; LIMA, N. C.; SIMILI, F. F. Efeito do dia de ocupação sobre a produção leiteira de vacas mestiças em pastejo rotacionado de forrageiras tropicais. Revista Brasileira de Zootecnia, Viçosa, v. 34, n. 3, p. 1051-1059, 2005.

SILVA, C. V.; LANA, R. P.; CAMPOS, J. M. S.; QUEIROZ, A. C.; LEÃO, M. I.; ABREU, D. C. Consumo, digestibilidade aparente dos nutrientes e desempenho de vacas leiteiras em pastejo com dietas com diversos níveis de concentrado e proteína bruta. Revista Brasileira de Zootecnia, Viçosa, MG, v. 38, n. 7, p. 1372-1380, 2009.

SILVA, D. J.; QUEIROZ, A. C. Análise de alimentos: métodos químicos e biológicos. 3. ed. Viçosa, MG: Editora UFV, 2002. 235 p.

SNIFFEN, C. J.; O'CONNOR, J. D.; VAN SOEST, P. S.; FOX, D. G.; RUSSEL, J. B. A net carbohydrate and protein system for evaluating cattle diets. II. 
Carbohydrate and protein availability. Journal of Animal Science, Champaign, v. 70, n. 11, p. 3562-3577, 1992.

SOUSA, B. M.; SATURNINO, H. M.; BORGES, A. L. C. C.; LOPES, F. C. F.; SILVA, R. R.; CAMPOS, M. M.; PIMENTA, M.; CAMPOS, W. E. Estimativa de consumo de matéria seca e de fibra em detergente neutro por vacas leiteiras sob pastejo, suplementadas com diferentes quantidades de alimento concentrado. Arquivos Brasileiros de Medicina Veterinária e Zootecnia, Belo Horizonte, v. 60, n. 4, p. 890-895, 2008.

STELZER, F. S.; LANA, R. P.; CAMPOS, J. M. S.; MANCIO, A. B.; PEREIRA, J. C.; LIMA, J. G. Desempenho de vacas leiteiras recebendo concentrado em diferentes níveis, associado ou não a própolis. Revista Brasileira de Zootecnia, Viçosa, MG, v. 38, n. 7, p. 13811389, 2009.

TEIXEIRA, R. M. A.; LANA, R. P.; FERNANDES, L. O.; OLIVEIRA, A. S.; QUEIROZ, A. C.; PIMENTEL, J. J. O. Desempenho produtivo de vacas da raça Gir leiteira em confinamento alimentadas com níveis de concentrado e proteína bruta nas dietas. Revista Brasileira de Zootecnia, Viçosa, MG, v. 39, n. 11, p. 2527-2534, 2010.
TEIXEIRA, R. M. A.; LANA, R. P.; FERNANDES, L. O.; OLIVEIRA, A. S.; CAMPOS, J. M. S.; PIMENTEL, J. J. O. Concentrate and crude protein levels in diets for dairy Gyr lineage cows grazing elephant-grass during the rainy season. Revista Brasileira de Zootecnia, Viçosa, MG, v. 40, n. 6, p. 1347-1355, 2011

TILLEY, J. M. A.; TERRY, R. A. A two-stage techniques for digestion of forage crops. Journal of British Grassland Society, Oxford, v. 18, n. 2, p. 104-111, 1963.

UNIVERSIDADE FEDERAL DE VIÇOSA - UFV. Sistema de análises estatísticas e genéticas - SAEG. Viçosa, MG: Versão 9.8. Viçosa: UFV, 1997.

VALADARES FILHO, S. C. Nutrição, avaliação de alimentos e tabelas de composição de alimentos para bovinos. In: REUNIÃO ANUAL DA SOCIEDADE BRASILEIRA DE ZOOTECNIA, 37., 2000, Viçosa, MG. Anais... Viçosa, MG: Sociedade Brasileira de Zootecnia, 2000. p. 267-338.

VAN SOEST, P. J. Nutritional ecology of the ruminants. 2. ed. Ithaca: Cornell University, 1994. 476 p.

WEISS, W. Energy prediction equations for ruminant feeds. In: CORNELL NUTRITION CONFERENCE FOR FEED MANUFACTURERS, 61., 1999, Ithaca. Proceedings... Ithaca: Cornell University, 1999. p. 176185. 
